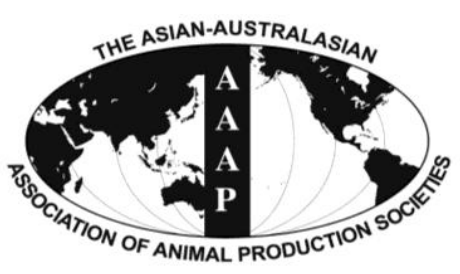

Open Access

Asian Australas. J. Anim. Sci.

Vol. 28, No. 7 : 1044-1052 July 2015

http://dx.doi.org/10.5713/ajas.14.0387

www.ajas.info

pISSN 1011-2367 elSSN 1976-5517

\title{
Modelling Pasture-based Automatic Milking System Herds: The Impact of Large Herd on Milk Yield and Economics
}

\author{
M. R. Islam*, C. E. F. Clark, S. C. Garcia, and K. L. Kerrisk \\ Dairy Science Group, Faculty of Veterinary Science, The University of Sydney, Camden, NSW 2570, Australia
}

\begin{abstract}
The aim of this modelling study was to investigate the effect of large herd size (and land areas) on walking distances and milking interval (MI), and their impact on milk yield and economic penalties when $50 \%$ of the total diets were provided from home grown feed either as pasture or grazeable complementary forage rotation (CFR) in an automatic milking system (AMS). Twelve scenarios consisting of 3 AMS herds $(400,600,800$ cows), 2 levels of pasture utilisation (current AMS utilisation of $15.0 \mathrm{t}$ dry matter $[\mathrm{DM}] /$ ha, termed as 'moderate'; optimum pasture utilisation of $19.7 \mathrm{t} \mathrm{DM} / \mathrm{ha}$, termed as 'high') and 2 rates of incorporation of grazeable complementary forage system (CFS: $0,30 \%$; CFS $=65 \%$ farm is CFR and 35\% of farm is pasture) were investigated. Walking distances, energy loss due to walking, MI, reduction in milk yield and income loss were calculated for each treatment based on information available in the literature. With moderate pasture utilisation and 0\% CFR, increasing the herd size from 400 to 800 cows resulted in an increase in total walking distances between the parlour and the paddock from 3.5 to $6.3 \mathrm{~km}$. Consequently, MI increased from 15.2 to $16.4 \mathrm{~h}$ with increased herd size from 400 to 800 cows. High pasture utilisation (allowing for an increased stocking density) reduced the total walking distances up to $1 \mathrm{~km}$, thus reduced the MI by up to $0.5 \mathrm{~h}$ compared to the moderate pasture, 800 cow herd combination. The high pasture utilisation combined with $30 \%$ of the farm in CFR in the farm reduced the total walking distances by up to $1.7 \mathrm{~km}$ and MI by up to $0.8 \mathrm{~h}$ compared to the moderate pasture and $800 \mathrm{cow}$ herd combination. For moderate pasture utilisation, increasing the herd size from 400 to 800 cows resulted in more dramatic milk yield penalty as yield increasing from c.f. 2.6 and $5.1 \mathrm{~kg} / \mathrm{cow} / \mathrm{d}$ respectively, which incurred a loss of up to \$AU 1.9/cow/d. Milk yield losses of $0.61 \mathrm{~kg}$ and $0.25 \mathrm{~kg}$ for every $\mathrm{km}$ increase in total walking distance (voluntary return trip from parlour to paddock) and every one hour increase in MI, respectively. The high pasture utilisation combined with $30 \%$ of the farm in CFR in the farm increased milk yield by up to $1.5 \mathrm{~kg} / \mathrm{cow} / \mathrm{d}$, thereby reducing loss by up to $\$ 0.5 / \mathrm{cow} / \mathrm{d}$ (c.f. the moderate pasture and 800 cow herd scenario). Thus, it was concluded that the successful integration of grazeable CFS with pasture has the potential to improve financial performance compared to the pasture only, large herd, AMS. (Key Words: Automatic Milking System, Complementary Forage System, Herd Size, Walking Distance, Milking Interval, Milk Yield, Profit)
\end{abstract}

\section{INTRODUCTION}

To maintain a pasture-based system whereby $>50 \%$ of the total diet is pasture (Garcia and Fulkerson, 2005), large herds will be required to walk significant distances in automatic milking system (AMS). Islam et al. (2013a, b) reported that AMS cows were required to walk greater than $1 \mathrm{~km}$ when the farm area was greater than 86 ha. They also reported growing pasture within $1 \mathrm{~km}$ of the dairy provided only $22 \%$ of the pasture requirement (when pasture

\footnotetext{
* Corresponding Author: M. R. Islam. Tel: +61-2-9036-7750, Fax: +61-2-4655-2374, E-mail: md.islam@ sydney.edu.au Submitted May 21, 2014; Revised Aug. 8, 2014; Accepted Oct. 25, 2014
}

provided $50 \%$ of total feed requirements) for a large herd of 800 cows, which required 200 ha grazing area. Excessively long walking distances are not only associated with an increased incidence of undesirably long milking intervals (MI) (Lyons et al., 2013; 2014) but are also associated with increased loss of energy (AFRC, 1993; CSIRO, 2007). Additional negative impacts on animal welfare and longevity are also likely as prolonged walking distances reported to be associated with high cortisol (an indicator of stress), impaired gaits or lameness (Coulon et al., 1998). Consequently, it could be expected that a large pasturebased AMS herd, may be associated with an increased risk of reduction in milk yield (MY) and thus economic loss. 
Pasture is the main source of home grown feed (HGF; any pasture or forages grown on farm and not purchased for feeding animals is referred here as HGF) on Australian dairy farms (Fulkerson and Doyle, 2001) in a predominantly pasture-based dairy production system. However, due to seasonal limitation of growth, pasture cannot supply more than $20 \mathrm{t}$ dry matter (DM)/ha/year. Growing more $\mathrm{HGF}$ based on the principles of complementary forage rotation (CFR; Garcia et al., 2008) may provide $28 \mathrm{t} \mathrm{DM} /$ ha grazeable forage (Islam et al., 2012), which has the potential to reduce the required land areas and thus walking distances in AMS (Islam et al., 2013b). Complementary forage rotation comprised of an annual rotation of three crops such as maize (Zea mays $\mathrm{L}$ ), forage rape (Brassica napus L) and a legume, field peas (Pisum sativum L) or Persian clover (Trifolium repesinatum L.) for conservation and grazing. Cost per $\mathrm{kg}$ DM of HGF was reportedly lower than the cost of purchased feeds (Chapman et al., 2008a, b). Farina et al. (2013) reported that pasture in association with grazeable plus conserved CFR was more profitable compared to the pasture only system in conventional milking. Farina et al. (2013) defined this system as a complementary forage system (CFS), which combined an area of CFR crop with an area of pasture in $35 \%$ and $65 \%$ of the farm area. Thus, this grazeable CFS has the potential to increase profitability of a large herd AMS farm compared to pasture-based AMS.

The objectives of this modelling study was to investigate the i) effect of increased herd sizes on walking distances and MI and establish their relationships with MY and economic consequences; and ii) impact of grazeable CFS in reducing walking distances, MI, MY, and loss/profit in pasture-based AMS.

\section{MATERIALS AND METHODS}

Twelve scenarios consisting of 3 AMS herds (400, 600, 800 cows), 2 levels of pasture utilisation (current AMS pasture utilisation of $15.0 \mathrm{t} \mathrm{DM} / \mathrm{ha}$, as 'moderate'; optimum pasture utilisation of $19.7 \mathrm{t} \mathrm{DM} / \mathrm{ha}$, as 'high') and 2 rates of grazeable CFS $(0,30 \%)$ were investigated. Pasture utilisation definition here and throughout the text referred as the annual amount of pasture harvested (consumed) per ha and converted into milk (Garcia and Fulkerson, 2005). A desktop model was developed ad hoc in MS Excel to determine the effect of herd sizes, pasture utilisation and rates of replacement CFR by pasture (i.e. 12 scenarios) on walking distances, MI, MY, and economic losses. Walking distances, estimation of energy loss due to walking, MI, MY and profit/loss due to increased herd sizes are calculated based on information in the literature as follows:

\section{Calculation of milking interval and walking distances}

The impact of walking distance (distance from parlour to paddock) on MI was shown to be $0.1 \mathrm{~h}$ per additional 100 $\mathrm{m}$ when the walking distance was between $100 \mathrm{~m}$ and $1 \mathrm{~km}$ (MI increased from 14.24 to $15.16 \mathrm{~h}$; Lyons, 2013). On this basis and in the absence of any additional published data, for modelling purposes it was assumed that MI will be increased (from $14 \mathrm{~h}$ ) by $1 \mathrm{~h}$ for every $\mathrm{km}$ walking distance from the parlour to the paddock. Thus, a MI of $14 \mathrm{~h}$ was considered as the baseline for paddocks immediately adjacent to the dairy, MI extended to $15 \mathrm{~h}$ at $1 \mathrm{~km}$ distance, and so on to $20 \mathrm{~h}$ at $6 \mathrm{~km}$.

Milking frequency (number of milkings occurring in a $24 \mathrm{~h}$ period; MF) was calculated by dividing 24 by MI (i.e. $\mathrm{MF}=24 / \mathrm{MI})$.

In order to consider return times from the paddock to the dairy as Lyons (2013) each MF was multiplied by 2 to calculate the number of voluntary 'trips' or trafficking events required to achieve a milking.

Actual or total walking distances were calculated by multiplying the walking distance (distance from parlour to paddock) given above against each MI with the number of voluntary trips (i.e. total walking $=$ walking distance from the parlour to paddock $\times$ no. of voluntary trips).

Land area requirement for walking distances from 1 to 6 $\mathrm{km}$ from the parlour to the paddock (total distances ranged from 0 to $14.4 \mathrm{~km}$ respectively) was taken from previous works (Islam et al., 2013a, b).

\section{Calculation of milk yield loss due to milking interval}

The relationship between MI and MY was developed using data available in the literature. Increasing MF from 1 (Erdman and Varner, 1995), to 2 (K. Kerrisk, personal communication; AMS research farm), 3 (Stockdale, 2006) and 4 (Erdman and Varner, 1995) has been reported to result in increases in MY from 19 to 25,29 , and $30 \mathrm{~kg}$, respectively. The MF was converted to $\mathrm{MI}(\mathrm{MI}=24 / \mathrm{MF})$ and a relationship between MI and MY was developed using the data of the AMS research farm (K. Kerrisk, personal communication), Stockdale (2006) and Erdman and Varner (1995) as:

$$
\begin{aligned}
& \text { Milk yield }(\mathrm{kg} / \mathrm{cow} / \mathrm{d})=-0.594 \times \mathrm{MI}+32.91 \\
& \left(\mathrm{R}^{2}=0.99\right)
\end{aligned}
$$

Milk yield loss (kg/cow/d) due to extended MI from 14 $\mathrm{h}$ to $20 \mathrm{~h}$ was calculated using equation 1 . At a MI of $14 \mathrm{~h}$, MY was calculated to be $24.6 \mathrm{~kg} / \mathrm{cow} / \mathrm{d}$, which was similar to the average yield of cows in AMS (25 kg/cow/d) whilst a MI of $20 \mathrm{~h}$ MY was calculated to have a daily MY of 21 $\mathrm{kg} / \mathrm{cow} / \mathrm{d}$. Net MY loss at each MI was calculated by the difference between yield at $14 \mathrm{~h}$ MI and yield at that 
particular MI.

The net MY loss (kg/cow/d) against each MI was multiplied by AU\$ 0.376 (AU\$ $/ \mathrm{kg}$ milk) in order to calculate economic loss per cow resulting from extended MI.

Calculation of milk yield loss due to walking distances and grazing

Milk yield loss caused by walking and grazing was calculated from the energy loss attributed to simultaneous grazing and walking, and total distances walked for each MI given above.

Metabolisable energy (ME) expended on walking to and from the parlour, and simultaneous grazing and walking against each total distance walked was calculated as:

$$
\begin{aligned}
\mathrm{ME}(\mathrm{MJ} / \mathrm{cow})=\mathrm{W}[\mathrm{C} \cdot \mathrm{DMI}(0.9-\mathrm{D})+0.026 \mathrm{H}] / \mathrm{k}_{\mathrm{m}} \\
(\mathrm{CSIRO}, 2007 ; \text { equation 2) }
\end{aligned}
$$

Where:

$\mathrm{W}=$ live weight of cows assumed as $600 \mathrm{~kg}$ (Farina et al., 2011);

$\mathrm{C}=0.0025$ constant for cattle;

DMI = dry mater intake from pasture $(10 \mathrm{~kg} / \mathrm{d})$ excluding supplementary DM assumed as $10 \mathrm{~kg}$ (i.e. $50 \%$ of the total diet is pasture or CFR; Garcia and Fulkerson, 2005);

$\mathrm{D}=$ digestibility of DM (decimal) assumed as 0.7 ;

$\mathrm{H}=$ horizontal equivalent of the distance walked $(\mathrm{km})$ computed as:

$$
\mathrm{H}=\mathrm{T}[(\min (1, \mathrm{SR} / \mathrm{SD}) /(0.057 \mathrm{GF}+0.16)+\mathrm{M}]
$$

(CSIRO, 2007; equation 3)

$\mathrm{T}=$ taken as average of 1.5 in the present study where values can range from 1.0 to 2.0 as terrain varies from level to steep;

SR = current grazing density (cows/ha) which was assumed as 4 and 5 for moderate and high pasture respectively and 5 and 5.7 for $30 \%$ CFR in moderate and high pasture respectively (Islam et al., 2013a);

$\mathrm{SD}=$ threshold for grazing density (cows/ha) considered the same as SR;

$\mathrm{GF}=$ availability of green forage (t DM/ha) assumed as 15.0 (Islam et al., 2013a, b) and 19.7 (Farina et al., 2011) t $\mathrm{DM} / \mathrm{ha}$ in moderate and high pasture utilisation in AMS. In addition 70:30 pasture:CFR forage availability was calculated based on yield of moderate and high pasture as above and CFR yield of $28.2 \mathrm{t} \mathrm{DM/ha} \mathrm{(Islam} \mathrm{et} \mathrm{al.,} \mathrm{2012);}$

$\mathrm{M}=$ total distances walked $(\mathrm{km})$ each day from the milking parlour to the paddock and return to the parlour based on average 2 visits/d.

$\mathrm{K}_{\mathrm{m}}=$ net efficiency of use of ME, which was calculated from the following equation:

$$
\mathrm{K}_{\mathrm{m}}=0.02 \mathrm{M} / \mathrm{D}+0.5
$$

Where,

$\mathrm{M} / \mathrm{D}$ usually referred to as ME content (MJ/kg DM) of a diet or pasture and was calculated from the following equation;

$$
\mathrm{M} / \mathrm{D}=0.172 \mathrm{DMD}-1.707 \quad(\mathrm{CSIRO}, 2007 ; \text { equation 4) }
$$

DMD = DM digestibility of pasture assumed as being constant at $70 \%$ resulting in $\mathrm{M} / \mathrm{D}$ being held constant at 10.3 (CSIRO, 2007).

Energy loss at 0 walking distance was considered as 0 . Energy loss due to a particular total walking distance was calculated by the difference between the energy loss attributed to that walking distance and the preceding walking distance. Energy loss was divided by 5.7 (as 5.7 $\mathrm{MJ} \mathrm{ME}$ is required to produce $1 \mathrm{~kg}$ milk; Nicol and Brookes, 2007) in order to calculate MY loss directly attributed to simultaneous walking and grazing and total walking distance.

Milk yield loss $(\mathrm{kg} / \mathrm{cow} / \mathrm{d})$ attributed to walking was again multiplied by AU\$ 0.376 (AU\$/kg milk) in order to calculate an economic loss per cow/d resulting to increasing walking distances.

\section{Relationship between land areas and milk yield or economic loss}

As mentioned above our goal was to determine the effect of herd sizes, pasture utilisation and rates of replacement CFR by pasture (i.e. 12 scenarios in methods) on walking distances, MI, MY, and economic losses. Previously, Islam et al. (2013a) calculated land areas required for all these scenarios. Thus, relationship between land areas and all parameters mentioned above were developed (Table 1). These relationships between land areas and different parameters were used to calculate all

Table 1. Relationships between land areas (' $x$ ', expressed in ha) and different parameters

\begin{tabular}{ll}
\hline Characters & \multicolumn{1}{c}{ Equations } \\
\hline Distance of paddocks from the parlour (km) & $0.012 \mathrm{x}-0.028$ \\
Milking interval (MI, h) & $0.012 \mathrm{x}+13.97$ \\
Milking frequency (number of milkings/d) & $-0.001 \mathrm{x}+1.69$ \\
ME loss due to grazing+walking (MJ ME/cow/d) & $0.095 \mathrm{x}+2.26$ \\
Distance walked per day (km) & $0.028 \mathrm{x}+0.68$ \\
Average number of voluntary trips (trips/d) & $-0.002 \mathrm{x}+3.38$ \\
Milk yield loss due to grazing+walking & $0.017 \mathrm{x}+0.21$ \\
(kg/cow/d) & \\
Milk yield loss due to milking interval $(\mathrm{kg} / \mathrm{cow} / \mathrm{d})$ & $0.007 \mathrm{x}-0.02$ \\
Losses due to walking and grazing (AU\$ $/ \mathrm{cow} / \mathrm{d})$ & $0.007 \mathrm{x}+0.08$ \\
Losses due to milking interval (AU $\$ \mathrm{cow} / \mathrm{d})$ & $0.003 \mathrm{x}-0.006$ \\
\hline
\end{tabular}


Table 2. Relationships between total walking distances between the parlour and the paddock $(\mathrm{x}, \mathrm{km})$ and different parameters

\begin{tabular}{ll}
\hline Characters & \multicolumn{1}{c}{ Equations } \\
\hline Area (ha) & $35.02 \mathrm{x}-21.87$ \\
Milking interval (h) & $0.42 \mathrm{x}+13.72$ \\
Milking frequency (no.) & $-0.036 \mathrm{x}+1.71$ \\
Energy loss due to grazing+walking & $3.48 \mathrm{x}-1.20$ \\
$\quad$ (MJ ME/cow/d) & \\
Average number of voluntary trips & $-0.071 \mathrm{x}+3.43$ \\
Milk yield loss due to grazing+walking & $0.61 \mathrm{x}-0.21$ \\
$\quad$ (kg/cow/d) & \\
Milk yield loss due to milking interval & $0.25 \mathrm{x}-0.17$ \\
$\quad$ kg/cow/d) & \\
AU\$ loss/cow/d for walking+grazing & $0.23 \mathrm{x}-0.08$ \\
AU\$ loss/cow/d for milking interval & $0.093 \mathrm{x}-0.06$ \\
Total milk loss (kg/cow/d) & $0.86 \mathrm{x}-0.38$ \\
Total AU\$ loss/cow/d & $0.32 \mathrm{x}-0.14$ \\
Milk accumulation rate $(\mathrm{kg} / \mathrm{h})$ & $-0.05 \mathrm{x}+1.75$ \\
\hline
\end{tabular}

parameters against scenarios related to herd sizes, pasture utilisation and rates of CFR utilisation in pasture-based AMS.

In addition, relationships between total walking distances between the parlour and the paddock (Table 2) and all parameters were also developed, which can be used to calculate MY loss or other parameters as required. Furthermore, relationships between $\mathrm{MI}$ and all other parameters were also developed (Table 3).

\section{RESULTS}

Effect of herd size on walking distances and milking
Table 3. Relationships between milking interval $(\mathrm{x}, \mathrm{h})$ and different parameters

\begin{tabular}{ll}
\hline Characters & \multicolumn{1}{c}{ Equations } \\
\hline Area (ha) & $84.21 \mathrm{x}-1176.5$ \\
Milking frequency (no.) & $0.085 \mathrm{x}+2.88$ \\
Total distance walk (km/d) & $2.38 \mathrm{x}-32.61$ \\
Distance from the parlour to paddock $(\mathrm{km})$ & $\mathrm{x}-14$ \\
Energy loss due to grazing+walking & $8.25 \mathrm{x}-113.98$ \\
$\quad$ MJ ME/cow/d) & \\
Average number of voluntary trips & $-0.17 \mathrm{x}+5.76$ \\
Milk yield loss due to grazing+walking & $1.45 \mathrm{x}-20.0$ \\
$\quad$ (kg/cow) & \\
Milk yield loss due to milking interval & $0.60 \mathrm{x}-8.35$ \\
$\quad$ (kg/cow/d) & \\
AU $\$$ loss/cow/d for walking+grazing & $0.54 \mathrm{x}-7.52$ \\
AU $\$$ loss/cow/d for milking interval & $0.22 \mathrm{x}-3.14$ \\
Total milk loss (kg/cow/d) & $2.04 \mathrm{x}-28.35$ \\
Total AU $\$$ loss/cow/d & $0.77 \mathrm{x}-10.66$ \\
Milk accumulation rate $(\mathrm{kg} / \mathrm{h})$ & $-0.12 \mathrm{x}+3.35$ \\
\hline
\end{tabular}

interval

With 'moderate' pasture utilisation, as herd size increased from 400 to 800 cows total walking distances from the parlour to the paddock increased from 1.2 to 2.4 $\mathrm{km}$ (Table 4). As a consequence of this increased distance, the number of voluntary trips (from parlour to paddock and vice versa) and thus MF decreased with increased herd size. Despite the decreased number of voluntary trips, total daily distances (that would have been travelled if the cows had a MF of 2) walked by cows increased from 3.5 to $6.3 \mathrm{~km}$. Consequently, MI increased from 15.2 to $16.4 \mathrm{~h}$ as herd size increased from 400 to 800 cows (Table 4).

Table 4. Effect of herd sizes, pasture utilisation $(\mathrm{P})$ and rates of grazeable complementary forage rotation (CFR) use on walking distances (from parlour to paddock [distance, $\mathrm{km}$ ] and total walking distance in $\mathrm{km}$ in a day), energy loss due to grazing and walking, milking frequency (MF) and milking interval (MI)

\begin{tabular}{|c|c|c|c|c|c|c|c|c|c|c|}
\hline $\begin{array}{l}\text { Herd size } \\
(n)\end{array}$ & $\begin{array}{c}\mathrm{P} \\
\text { (t DM/ha) }\end{array}$ & $\begin{array}{l}\text { CFR } \\
(\%)\end{array}$ & $\begin{array}{c}\text { SR } \\
\text { (cow/ha) }\end{array}$ & $\begin{array}{c}\text { Area } \\
\text { (ha) }\end{array}$ & $\begin{array}{c}\text { Distance } \\
(\mathrm{km})\end{array}$ & $\begin{array}{c}\text { MF } \\
\text { (no./d) }\end{array}$ & $\begin{array}{c}\text { No. of } \\
\text { voluntary trips }\end{array}$ & $\begin{array}{c}\text { Total distance } \\
\text { walked } \\
(\mathrm{km} / \mathrm{d})\end{array}$ & $\begin{array}{l}\text { MI } \\
\text { (h) }\end{array}$ & $\begin{array}{c}\text { Energy loss } \\
(\mathrm{MJ} \mathrm{ME} / \text { cow/d) }\end{array}$ \\
\hline \multirow[t]{4}{*}{400} & 15.0 & 0 & 4.0 & 100 & 1.2 & 1.6 & 3.2 & 3.5 & 15.2 & 11.0 \\
\hline & & $30^{\mathrm{a}}$ & 5.0 & 80 & 0.9 & 1.6 & 3.2 & 2.9 & 14.9 & 9.1 \\
\hline & 19.7 & 0 & 5.0 & 80 & 0.9 & 1.6 & 3.2 & 2.9 & 14.9 & 9.1 \\
\hline & & $30^{\mathrm{b}}$ & 5.7 & 70 & 0.8 & 1.6 & 3.2 & 2.7 & 14.8 & 8.1 \\
\hline \multirow[t]{4}{*}{600} & 15.0 & 0 & 4.0 & 150 & 1.8 & 1.5 & 3.1 & 4.9 & 15.8 & 16.0 \\
\hline & & $30^{\mathrm{a}}$ & 5.0 & 120 & 1.4 & 1.6 & 3.1 & 4.1 & 15.4 & 13.0 \\
\hline & 19.7 & 0 & 5.0 & 120 & 1.4 & 1.6 & 3.1 & 4.1 & 15.4 & 13.0 \\
\hline & & $30^{\mathrm{b}}$ & 5.7 & 110 & 1.3 & 1.6 & 3.2 & 3.8 & 15.3 & 12.0 \\
\hline \multirow[t]{4}{*}{800} & 15.0 & 0 & 4.0 & 200 & 2.4 & 1.5 & 3.0 & 6.3 & 16.4 & 20.9 \\
\hline & & $30^{\mathrm{a}}$ & 5.0 & 160 & 1.9 & 1.5 & 3.1 & 5.2 & 15.9 & 16.9 \\
\hline & 19.7 & 0 & 5.0 & 160 & 1.9 & 1.5 & 3.1 & 5.2 & 15.9 & 16.9 \\
\hline & & $30^{\mathrm{b}}$ & 5.7 & 140 & 1.6 & 1.5 & 3.1 & 4.6 & 15.6 & 15.0 \\
\hline
\end{tabular}

SR, stocking rate; ME, metabolisable energy.

${ }^{1}$ Calculated ME for grazing and walking at 0 walking distances (i.e. $<1 \mathrm{~km}$ ) is $44.9 \mathrm{MJ} / \mathrm{cow} / \mathrm{d}$.

${ }^{\mathrm{a}}$ Pasture:CFR = 70:30 of land where pasture was 10.5 t and CFR was 8.5 t DM/ha (CFR yield, $28.2 \mathrm{t} \mathrm{DM/ha).}$

${ }^{\mathrm{b}}$ Pasture:CFR = 70:30 of land where pasture was $13.8 \mathrm{t}$ and CFR was $\left.8.5 \mathrm{t} \mathrm{DM/ha} \mathrm{(CFR} \mathrm{yield,} 28.2 \mathrm{t} \mathrm{DM} / \mathrm{ha}\right)$ 
In comparison to the moderate pasture utilisation scenario, the high pasture utilisation scenario resulted in total walking distances that were reduced by $1.1 \mathrm{~km}$, and an average MI that was reduced by $0.5 \mathrm{~h}$ (Table 4). The same effect was achieved with the 800 cow herd when the moderate pasture scenario was compared to the moderate pasture with 30\% CFR scenario. However, greater gains were achieved when the 800 cow, moderate pasture scenario was compared to the 800 cow high pasture utilisation with $30 \%$ CFR scenario with total walking distances reduced by $1.7 \mathrm{~km}$ and MI reduced by $0.8 \mathrm{~h}$ (Table 4).

\section{Effect of herd size on energy loss attributed to walking and grazing}

Increasing herd size from 400 to 800 cows with moderate pasture utilisation increased energy loss from 11 to $21 \mathrm{MJ} \mathrm{ME} / \mathrm{cow} / \mathrm{d}$ through increased total daily walking distances from 3.5 to $6.3 \mathrm{~km} / \mathrm{cow} / \mathrm{d}$ (Table 4 ). The high pasture utilisation and moderate pasture (70):CFR (30) combination scenarios reduced energy loss by $4 \mathrm{MJ}$ $\mathrm{ME} / \mathrm{cow} / \mathrm{d}$ compared to the moderate pasture utilisation scenario for 800 cows. This energy loss was further reduced from 20.9 in moderate pasture to $15.0 \mathrm{MJ} \mathrm{ME} / \mathrm{cow} / \mathrm{d}$ when high pasture:CFR scenario was modelled for the 800 cow herd (Table 4).

Our results showed that energy loss could be 3.5 MJ $\mathrm{ME} / \mathrm{cow} / \mathrm{d}$ for every $\mathrm{km}$ increase in total walking distances between the parlour and the paddock (Table 2).

\section{Effect of herd size on milk yield and economic loss}

With moderate pasture utilisation, as herd size increased from 400 to 800 cows total MY loss (for walking, grazing and MI) increased from 2.6 to $5.1 \mathrm{~kg} / \mathrm{cow} / \mathrm{d}$ (Table 5). Greater than $70 \%$ of this loss was attributed to the increased walking and foraging whilst less than $30 \%$ was attributed to the reduced MI's (Table 5). Thus, with moderate pasture utilisation total economic loss due to increased walking distances (and grazing) and reduced MI was AU\$ 1.0/cow/d for cows in the 400 cow herd and AU\$ 1.9/cow/d for cows in the 800 cow herd (Table 5).

The high pasture utilisation and moderate pasture:CFR scenarios reduced MY loss by $1 \mathrm{~kg} / \mathrm{cow} / \mathrm{d}$, thereby reducing loss by AU $\$ 0.4 / \mathrm{cow} / \mathrm{d}$ compared to the moderate pasture scenario with 800 cows herd. The 800 cow, high pasture:CFR scenario reduced MY loss by $1.5 \mathrm{~kg} / \mathrm{cow} / \mathrm{d}$, and reduced loss by AU\$ $0.5 / \mathrm{cow} / \mathrm{d}$ compared to the moderate pasture scenario.

Our results also showed that the MY loss could be 0.86 $\mathrm{kg} / \mathrm{cow} / \mathrm{d}$ for every $\mathrm{km}$ increase in total walking distances between the parlour and the paddock (Table 2). This increased a loss of AU $\$ 0.32$ per cow/d (Table 2) for every $\mathrm{km}$ increase in total distance walked. Also, we found 0.6 $\mathrm{kg} / \mathrm{cow} / \mathrm{d}$ reduction in MY for each $\mathrm{h}$ increase in MI, which incurred AU\$ 0.22 loss/cow/d (Table 3).

\section{DISCUSSION}

The main objective of this study was to investigate the effect of large herd size (and associated land areas) on walking distances and MI, and their impact on modelled MY, and economic loss when $50 \%$ of the total diet was provided from HGF (either as pasture or pasture in combination with CFR). As expected, increased herd size

Table 5. Effect of herd sizes, pasture utilisation $(\mathrm{P})$ and rates of grazeable complementary forage rotation (CFR) use on milk yield and economic losses due to walking distances and milking interval

\begin{tabular}{|c|c|c|c|c|c|c|c|c|c|c|}
\hline $\begin{array}{l}\text { Herd size } \\
(n)\end{array}$ & $\begin{array}{c}\mathrm{P} \\
\text { (t DM/ha) }\end{array}$ & $\begin{array}{l}\text { CFR } \\
(\%)\end{array}$ & $\begin{array}{c}\mathrm{SR} \\
\text { (cow/ha) }\end{array}$ & $\begin{array}{c}\text { Area } \\
\text { (ha) }\end{array}$ & $\begin{array}{c}\text { Milk yield loss } \\
\text { due to } \\
\text { grazing+ } \\
\text { walking } \\
(\mathrm{kg} / \text { cow } / \mathrm{d})\end{array}$ & $\begin{array}{l}\text { Milk yield loss } \\
\text { due to milking } \\
\text { interval } \\
(\mathrm{kg} / \mathrm{cow} / \mathrm{d})\end{array}$ & $\begin{array}{l}\text { Loss/cow/d for } \\
\text { walking } \\
\text { +grazing } \\
\text { (AU\$) }\end{array}$ & $\begin{array}{l}\text { Loss/cow/d } \\
\text { for milking } \\
\text { interval } \\
\text { (AU\$) }\end{array}$ & $\begin{array}{c}\text { Total milk } \\
\text { loss } \\
(\mathrm{kg} / \mathrm{cow} / \mathrm{d})\end{array}$ & $\begin{array}{c}\text { Total } \\
\text { loss/cow/d } \\
(\text { AU\$) }\end{array}$ \\
\hline \multirow[t]{4}{*}{400} & 15.0 & 0 & 4.0 & 100 & 1.9 & 0.69 & 0.73 & 0.26 & 2.6 & 1.0 \\
\hline & & $30^{\mathrm{a}}$ & 5.0 & 80 & 1.6 & 0.55 & 0.60 & 0.21 & 2.2 & 0.8 \\
\hline & 19.7 & 0 & 5.0 & 80 & 1.6 & 0.55 & 0.60 & 0.21 & 2.2 & 0.8 \\
\hline & & $30^{\mathrm{b}}$ & 5.7 & 70 & 1.4 & 0.48 & 0.53 & 0.18 & 1.9 & 0.7 \\
\hline \multirow[t]{4}{*}{600} & 15.0 & 0 & 4.0 & 150 & 2.8 & 1.05 & 1.05 & 0.40 & 3.9 & 1.5 \\
\hline & & $30^{\mathrm{a}}$ & 5.0 & 120 & 2.3 & 0.84 & 0.86 & 0.32 & 3.1 & 1.2 \\
\hline & 19.7 & 0 & 5.0 & 120 & 2.3 & 0.84 & 0.86 & 0.32 & 3.1 & 1.2 \\
\hline & & $30^{\mathrm{b}}$ & 5.7 & 110 & 2.1 & 0.76 & 0.79 & 0.29 & 2.9 & 1.1 \\
\hline \multirow[t]{4}{*}{800} & 15.0 & 0 & 4.0 & 200 & 3.7 & 1.40 & 1.38 & 0.53 & 5.1 & 1.9 \\
\hline & & $30^{\mathrm{a}}$ & 5.0 & 160 & 3.0 & 1.12 & 1.12 & 0.43 & 4.1 & 1.5 \\
\hline & 19.7 & 0 & 5.0 & 160 & 3.0 & 1.12 & 1.12 & 0.43 & 4.1 & 1.5 \\
\hline & & $30^{\mathrm{b}}$ & 5.7 & 140 & 2.6 & 0.98 & 0.99 & 0.37 & 3.6 & 1.4 \\
\hline
\end{tabular}

SR, stocking rate.

${ }^{\mathrm{a}}$ Pasture:CFR = 70:30 of land where pasture was $10.5 \mathrm{t}$ and CFR was $\left.8.5 \mathrm{t} \mathrm{DM/ha} \mathrm{(CFR} \mathrm{yield,} 28.2 \mathrm{t} \mathrm{DM} / \mathrm{ha}\right)$.

${ }^{\mathrm{b}}$ Pasture:CFR = 70:30 of land where pasture was $13.8 \mathrm{t}$ and CFR was $\left.8.5 \mathrm{t} \mathrm{DM/ha} \mathrm{(CFR} \mathrm{yield,} 28.2 \mathrm{t} \mathrm{DM} / \mathrm{ha}\right)$ 
increased both walking distances and MI. Such increases in walking distances and MI impacted negatively on MY and were associated with an economic cost.

Modelled reductions in milk yield in cows were predominantly explained by the energy expenditure directly associated with walking and foraging longer distances as opposed to those created through the resultant increases in MI. Islam et al. (2015a,b; in press) reported that grazing areas of herbage greater than 86 ha increases walking distances and reduces the milk yield in AMS. Thus, increasing the amount of herbage grown within this area through the use of CFR would minimise any milk yield penalty.

\section{Effect of herd size on walking distances and milk yield}

Not surprisingly increased walking distances and consequent increases in energy expenditure were observed as herd size increased. Our study indicated that the energy loss of cows across all HGF scenarios increased on average by $87 \%$ ( 9.3 to $17.4 \mathrm{MJ} \mathrm{ME}$ ), with the increase in herd size from 400 to 800 cows. Thus, the net reduction in MY could also be as high as $87 \%$ (on average from 1.6 to $3.1 \mathrm{~kg}$ milk reduction/cow/d) with the increase in herd size from 400 to 800 cows, when the base MY was considered as 25 $\mathrm{kg} / \mathrm{cow} / \mathrm{d}$. Our results also indicated that the loss in energy and MY would be $3.5 \mathrm{MJ} \mathrm{ME}$ and $0.86 \mathrm{~kg}$ for every additional $\mathrm{km}$ walked.

Interestingly, Thomson and Barnes (1993) estimated energy costs of 2.6 and 7.1 MJ ME/d, and reductions in MY of 0.45 and 1.2 litres for cows walking 4 and $8 \mathrm{~km} / \mathrm{d}$, respectively (relative to a control group which was walking $<0.5 \mathrm{~km} / \mathrm{d}$ ) based on ARC (1984) and Holmes and Wilson (1982). These losses or costs are considerably lower than those modelled in the current study. The discrepancy is likely to be attributed to the differences in body weight of cows. Cows modelled in the present study were heavier (600 kg) than the cows in the Thomson and Barnes (1993) study $(400 \mathrm{~kg}$ ) and it is known that heavier cows use more energy for walking than lighter cows at similar distances (ARC, 1980; Schütz et al., 2006). It has been reported (Brody, 1945; Ribiero et al., 1977; ARC 1980) that the Bos taurus cattle use $2 \mathrm{~J} / \mathrm{m}$ per $\mathrm{kg}$ liveweight (speed 0.5 to 1.4 $\mathrm{m} / \mathrm{s}$; weight 383 to $430 \mathrm{~kg}$ ) for walking. According to this calculation, energy cost (per km) for walking only (between the paddock and the parlour) in our study would be $1.2 \mathrm{MJ}$ $\mathrm{ME} / \mathrm{cow}$ out of total 3.5 MJ ME/cow energy cost. Thus, energy cost for simultaneous grazing and walking per $\mathrm{km}$ would be twice $(2.3 \mathrm{MJ} / \mathrm{cow} / \mathrm{km}$; i.e. $3.5 \mathrm{minus} 1.2 \mathrm{MJ}$ $\mathrm{ME} / \mathrm{cow}$ ) the rate of walking only. If it were assumed that the energy required for walking whilst grazing was equivalent to the energy expended for walking (to traffic somewhere as opposed to harvesting), it is likely that the energy expended during foraging would be partitioned equally between the distinct activities of grazing and walking at the rate of $\sim 1.2 \mathrm{MJ} / \mathrm{cow} / \mathrm{km}$. Double energy loss in simultaneous grazing and walking compared to walking only can be explained by the energy cost due to biting during grazing. di Marco et al. (1996) reported an increased energy cost with increased biting rate. These energy costs due to simultaneous walking and grazing during foraging as well as due to walking only were instrumental in reductions in MY of cows with increased herd size in AMS.

The impact of walking on MY has been shown to be breed dependent (D'hour et al., 1994; Coulon et al., 1998) as certain breeds expend less energy when walking which allows them to mobilise body reserves for milk production more efficiently (Coulon et al., 1998). In addition, Coulon et al. (1998) reported a significant increase in somatic cell counts and suggested that traumatic and non-infectious inflammation could be induced by walking. They observed a relationship between udder conformation and the sharp decrease in MY associated with walking. Walking stress has also been shown to influence respiration rate, rectal temperature, haemoglobin, packed cell volume, plasma glucose, calcium, phosphorous, amino acid linked enzymes, adrenal and thyroid hormones in sheep (Sejian et al., 2012). Whilst it is not reported in the literature, such impacts may also be observed in cows which walk long distances.

Thus, walking long distances may impact negatively on MY; directly through the energy costs; and through physiological impacts inhibiting MY.

\section{Effect of herd size on milking interval and milk yield}

In addition to walking distances, increased herd sizes in our study also increased MI of AMS cows. As increased herd sizes increased walking distances, our results indicate $0.42 \mathrm{~h}$ increase in MI for every $\mathrm{km}$ increase in total walking distances. However, an increase in the distance between the paddock and the parlour up to $0.5 \mathrm{~km}$ appeared to be unrelated to a change in MI (Jagtenburg and Lent, 2000; Lyons, 2013). There is no literature to support this assumption that the impact of walking distance on MI is a linear relationship. We recognise the possibility that negative impact of walking distance may in fact be significantly higher at extreme distances. Furthermore, it is possible that the number of cows that voluntarily traffic back to the dairy from furthermost paddocks may in fact be significantly reduced. If a large number of cows do not return to the dairy then it is possible that MI will extend dramatically if farm staffs do not intervene to encourage cows to traffic to the dairy at regular intervals.

Our results also showed $0.6 \mathrm{~kg}$ loss in MY for each $\mathrm{h}$ increase in MI. Thus, $\$ 0.22$ loss might occur for each hour increases in MI. In agreement with our results, a negative relationship between MI and MY was reported previously (Ouweltjes, 1998; Lyons, 2013). It is generally agreed that 
the negative relationship between $\mathrm{MI}$ and $\mathrm{MY}$ can be explained in part by a reduction in milk accumulation rate (Stelwagen and Knight, 1997; Lyons, 2013), which has been reported to be in the order of $0.12 \mathrm{~kg}$ milk per $\mathrm{h}$ of MI but is strongly dependent on many factors including the extent of the MI. This reduction in milk accumulation is likely to be associated with reduced udder health (Hammer et al., 2012). Extended MI's can also impact on MY through the accumulation of a negative feedback protein or other inhibitory protein, which inhibits milk secretion (Wilde et al., 1995; Collier et al., 2012).

\section{Impact of grazeable complementary forage system on walking distance and milking interval, milk yield and economic loss}

Our results indicated that in an 800 cow herd, the incorporation of grazeable CFS into the farm system in association with pastures $(30: 70)$ had the potential to: i) reduce walking distances of large AMS herds by 1.0 to 1.7 $\mathrm{km}$; ii) reduce MI by 0.5 to $1 \mathrm{~h}$; iii) reduce energy loss by 3 to $6 \mathrm{MJ} / \mathrm{cow} / \mathrm{d}$; iv) increase MY by up to $1.5 \mathrm{~kg} / \mathrm{cow} / \mathrm{d}$; and v) improve financial performance by up to AU\$ $0.5 /$ cow/d. These advantages of CFS were created through the improved potential created by CFR to growing more HGF within the defined farm area (28 t DM/ha; Islam et al., 2012) compared to the assumed pasture utilisation levels (15 to $20 \mathrm{t} \mathrm{DM/ha;} \mathrm{in} \mathrm{conventional} \mathrm{AMS} \mathrm{and} \mathrm{Farina} \mathrm{et} \mathrm{al.,}$ 2011). Farina et al. (2013) reported on the economic viability of the CFS in conventional milking system, which would be expected to be further enhanced with a large AMS herd as a result of the above reported MY and financial costs.

It should be mentioned that we did not model the location of the CFR and the distance between it and the parlour but recognise that planting in close vicinity to the dairy could further reduce average annual walking distances through concentrating a higher proportion of the HGF in close vicinity to the dairy.

\section{Risk and opportunities of grazeable complementary forage system}

Despite the reported potentials of CFS (Farina et al., 2013) to improve whole-farm performance in AMS, it is essential to note that CFS requires intensive management, relatively high inputs (e.g. $\mathrm{N}$ and water) and requires more water during less favourable climatic uncertainties such as in El-Niño years (Islam et al., 2012; Islam et al., 2015a,b [In press]). Regardless of the water requirements, if the farm has a plentiful and secure water source, the water use efficiency of CFR was considerably higher than pasture resulting in significant increases in $\mathrm{kg}$ DM per unit of water applied (Garcia et al., 2008; Islam and Garcia, 2012).

Economic factors: Chapman et al. (2008a, b) reported that pasture (or HGF in general) can usually be supplied at a lower cost per $\mathrm{kg}$ DM compared to purchased feed or concentrates. Islam et al. (2012) in a modelling study reported that $28 \mathrm{t} \mathrm{DM} / \mathrm{ha} / \mathrm{yr}$ grazeable CFS is achievable compared to current $15 \mathrm{t} \mathrm{DM} / \mathrm{ha}$ from pastures for AMS cows. Thus, the greatest impact of introducing grazeable CFS in the large herd AMS farming system can occur by increasing the consumption of HGF, which could significantly improve farm profitability. Fariña et al. (2011) reported an estimated total of $\sim 28,000 \mathrm{~L} \mathrm{MY} / \mathrm{ha} / \mathrm{yr}$ from HGF with $65 \%$ pasture and $35 \%$ CFR (grazeable plus conserved). Fariña et al. (2013) also reported lower financial risks associated with such system compared to the pasture alone system. Similarly, Chapman et al. (2008b) also reported lower financial risks created through the integration of different forage crops with perennial pastures compared to $100 \%$ perennial ryegrass in dryland farms. Therefore, it is envisaged that grazeable CFS has the potential to increase profits when incorporated to large AMS herds.

Supply of grazeable forages in critical periods of supply: Islam et al. (2012) reported that grazeable CFS has the ability to supply forages for AMS herds for at least 8 months of the year. However, these researchers identified the most critical periods when forage supply may not be available were approximately 2 months immediately after sowing in summer and 2 months after sowing in autumn. However, as grazeable CFR in our study was considered to supply $38 \%$ (in 'high'pasture) to $44 \%$ (in 'moderate' pasture) of total HGF supply in 70:30 CFS, CFR should be viewed as a complementary to pastures.

Thus, grazeable CFS could complement pastures by supplying large volumes of HGF particularly in critical periods, reduce the overall cost of feed and purchase of concentrate feeds, reduce walking distance and MI, and reduce MY penalties to improve farm economy in large herd AMS systems. However, one limitation of this modelling study was that a condition of cow behaviour could hardly be understood in relation to walking distances and MI of cows in AMS. Second, the modelling was based on available data on walking distance, which was between $100 \mathrm{~m}$ and $1 \mathrm{~km}$, and MI that increased from 14.24 to 15.16 $\mathrm{h}$, which inevitably provided linear relationships between variables of interest ( $x$ and $y$ ). However, in practice these relationships may not be linear. Third, a 'perfect layout' of the AMS farm was modelled, which also may or may not exist in practice.

\section{CONCLUSION}

Our study revealed that increased herd size resulted in increased walking distances of cows in pasture-based AMS. Increased walking distances led to increased energy loss 
and MI of cows, which further led to the reduction in MY and economic loss with increased herd size in pasture-based AMS. However, grazeable CFS (CFR:pasture 30:70) have the potential to reduce walking distances by up to $1.7 \mathrm{~km}$, MI by up to $\sim 1 \mathrm{~h}$, energy loss by up to $6 \mathrm{MJ} \mathrm{ME/cow/d} \mathrm{and}$ financial loss by up to AU\$ $0.5 / \mathrm{cow} / \mathrm{d}$ by increasing MY by up to $1.5 \mathrm{~kg} / \mathrm{cow} / \mathrm{d}$ for a large herd cows in AMS compared to pasture-based AMS only. Grazeable CFS has the potential to diversify forage base in the system and thus lower financial risks by integrating forage crops with pasture particularly when pasture is in short supply. However, grazeable CFS requires intensive management, high inputs and requires more water under climatic uncertainties such as in El-Niño years. These results generated through modelling would be enhanced through field research investigating the impact of increased herd size on walking distances, energy loss, MI, MY, and whole farm profitability.

\section{ACKNOWLEDGMENTS}

The authors thank the Dairy Research Foundation for its support of the Dairy Science Group and the investors of the Future Dairy project (Dairy Australia, NSW Department of Primary Industries, The University of Sydney, and DeLaval).

\section{REFERENCES}

AFRC. 1993. Energy and Protein Requirements of Ruminants. An Advisory Manual Prepared by the AFRC Technical Committee on Responses to Nutrients. Compiled by G. Alderman, in collaboration with B. R. Cottrill. CAB International, Wallingford, UK.

ARC. 1980. The Nutrient Requirements of Ruminant Livestock. Commonwealth Agricultural Bureaux, Slough, UK.

ARC. 1984. The Nutrient Requirements of Livestock. Technical Review by an Agricultural Research Council Working Party. Commonwealth Agricultural Bureaux. p. 101.

Brody, S. 1945. Bioenergetics and Growth. With Special Reference to the Efficiency Complex in Domestic Animals. Reinhold. New York.

Chapman, D. F., S. N. Kenny, D. Beca, and I. R. Johnson. 2008a. Pasture and forage crop systems for non-irrigated dairy farms in southern Australia. 1. Physical production and economic performance. Agric. Syst. 97:108-125.

Chapman, D. F., S. N. Kenny, D. Beca, and I. R. Johnson. 2008 b. Pasture and forage crop systems for non-irrigated dairy farms in southern Australia. 2. Inter-annual variation in forage supply, and business risk. Agric. Syst. 97:126-138.

Collier, R. J., L. L. Hemandez, and N. D. Horseman. 2012. Serotonin as a homeostatic regulator of lactation. Domest. Anim. Endocrinol. 43:161-170.

Coulon, J. B., P. Pradel, T. Cochard, and B. Poutrel. 1998. Effect of extreme walking conditions for dairy cows on milk yield, chemical composition, and somatic cell count. J. Dairy Sci.
81:994-1003.

CSIRO. 2007. Nutrient Requirements of Domesticated Ruminants. CSIRO Publishing, Collingwood, VIC, Australia.

D'hour, P., A. Hauwuy, J. B. Coulon, and J. P. Garel. 1994. Walking and dairy cattle performance. Ann. Zootech. (Paris) 43:369-378.

di Marco, O. N., M. S. Aello, and D. G. Méndez. 1996. Energy expenditure of cattle grazing on pastures of low and high availability. Anim. Sci. 63:45-50.

Erdman, R. A. and M. Varner. 1995. Fixed yield responses to increased milking frequency. J. Dairy Sci. 78:1199-1203.

Fariña, S. R., S. C. Garcia, and W. J. Fulkerson. 2011. A complementary forage system whole-farm study: Forage utilization and milk production. Anim. Prod. Sci. 51:460-470.

Fariña, S. R., A. Alford, S. C. Garcia, and W. J. Fulkerson. 2013. An integrated assessment of business risk for pasture-based dairy farm systems intensification. Agric. Syst. 115:10-20.

Garcia, S. C. and W. J. Fulkerson. 2005. Opportunities for future Australian dairy systems: A review. Aust. J. Exp. Agric. 45:1041-1055.

Garcia, S. C., W. J. Fulkerson, and S. U. Brookes. 2008. Dry matter production, nutritive value and efficiency of nutrient utilization of a complementary forage rotation compared to a grass pasture system. Grass Forage Sci. 63:284-300.

Hammer, J. F., J. M. Morton, and K. L. Kerrisk. 2012. Quartermilking-, quarter-, udder- and lactation-level risk factors and indicators for clinical mastitis during lactation in pasture-fed dairy cows managed in an automatic milking system. Aust. Vet. J. 90:167-174.

Holmes, C. W. and G. F. Wilson. 1982. Milk Production From Pasture. Butterworths, Wellington, NZ.

Islam, M. R. and S. C. Garcia. 2012. Effects of sowing date and nitrogen fertilizer on forage yield, nitrogen- and water-use efficiency and nutritive value of an annual triple-crop complementary forage rotation. Grass Forage Sci. 67:96-110.

Islam, M. R., S. C. Garcia, and K. L. Kerrisk. 2012. A modelling approach to screen grazeable forage options for automatic milking system herds. In: Proceedings of Australasian Dairy Science Symposium 2012 (Eds. J. Jacobs, S. C. Garcia, S. Little, D. Barber, G. Edwards, J. Roche, J. Jago, and D. Pacheco). National Dairy Alliance: Melbourne, Australia. pp. 459-460.

Islam, M. R., S. C. Garcia, C. E. F. Clark, and K. L. Kerrisk. 2013a. System fitness of grazeable forages for large herds in automatic milking system. Proc. Int. Grassl. Congr. pp. 17171718.

Islam, M. R., C. E. F. Clark, K. L. Kerrisk, S. C. Garcia, and N. A. Lyons. 2013b. Land areas required, associated walking distance and milking interval for large herds in pasture-based automatic milking system. Paper presented in Precision Dairy Conference, June 2013; Rochester, MN, USA.

Islam, M. R., S. C. Garcia, C. E. F. Clark, and K. L. Kerrisk. 2015a. Modelling pasture-based automatic milking system herds: grazeable forage options. Asian Australas. J. Anim. Sci. 28:703-715.

Islam, M. R., S. C. Garcia, C. E. F. Clark, and K. L. Kerrisk. 2015b. Modelling pasture-based automatic milking system herds: system fitness of grazeable home-grown forages, land areas and walking distances. Asian Australas. J. Anim. Sci. 
28:903-910.

Jagtenberg, K. and J. van Lent. 2000. Milking robots and grazing. Praktijkonderzoek Rundvee, Schapen en Paarden. 13:7-9.

Lyons, L., K. L. Kerrisk, and S. C. Garcia. 2014. Milking frequency management in pasture-based automatic milking system: A review. Livest. Sci. 159:102-116.

Lyons, N. A., K. L. Kerrisk, and S. C. Garcia. 2013. Comparison of 2 systems of pasture allocation on milking intervals and total daily milk yield of dairy cows in a pasture-based automatic milking system. J. Dairy Sci. 96:4494-4504.

Lyons, N. A. 2013. Investigations on Variable Milking Intervals, Cow Performance and Grazing Behaviour in a Pasture-based Automatic Milking System. Ph.D. Thesis, Faculty of Veterinary Science, The University of Sydney, NSW, Australia.

Nicol, A. M. and I. M. Brookes. 2007. The metabolisable energy requirements of grazing livestock. In 'Pasture and Supplements for Grazing Animals: Proceedings of the New Zealand Society of Animal Production 2007' (Eds. P. V. Rattray, I. M. Brookes, and A. M. Nicol). Occasional Publication No. 14, New Zealand. pp. 151-172.

Ouweltjes, W. 1998. The relationship between milk yield and milking interval in dairy cows. Livest. Prod. Sci. 56:193-201.
Ribiero, J. M. D. C. R., J. M. Brockway, and A. J. F. Webster. 1977. A note on the energy cost of walking in cattle. Anim. Prod. 25:107-110.

Schütz, K., D. Davison, and L. Matthews. 2006. Do different levels of moderate feed deprivation in dairy cows affect feeding motivation? Appl. Anim. Behav. Sci. 101:253-263.

Sejian, V., V. P. Maurya, and S. M. K. Naqvi. 2012. Effect of walking stress on growth, physiological adaptability and endocrine responses in Malpura ewes in a semi-arid tropical environment. Int. J. Biometeorol. 56:243-252.

Stelwagen, K. and C. H. Knight. 1997. Effect of unilateral once or twice daily milking of cows on milk yield and udder characteristics in early and late lactation. J. Dairy Res. 64:487494.

Stockdale, C. R. 2006. Influence of milking frequency on the productivity of dairy cows. Aust. J. Exp. Agric. 46:965-974.

Thomson, N. A. and M. L. Barnes. 1993. Effect of distance walked on dairy production and milk quality. Proc. NZ Soc. Anim. Prod. 53:69-72.

Wilde, C. J., C. V. P. Addey, L. M. Boddy, and M. Peaker. 1995. Autocrine regulation of milk secretion by a protein in milk. Biochem. J. 305:51-58. 